\title{
10. STRATEGIC DIMENSIONS OF PERMANENT MUSICAL EDUCATION AS A PART OF THE DEVELOPMENT OF PERSONALITY'S MUSICAL CULTURE
}

Marina Cosumov ${ }^{110}$

\begin{abstract}
Education is a sustainable human development strategic resource in postmodern society, being historically, culturally, socially, economically placed in time and space. The educational reform, based on curricular approach, involves radical changes in musical and artistic education, and this is "a precondition for the formation of an intelligent personality, with high moral and spiritual aspirations" [3]. The valuation of the arts products will foster musical artistic scope concern and it will ensure continuity in connection with art of music.
\end{abstract}

Key words: permanent musical and artistic education, musical values, independent musical and artistic knowledge

\section{Introduction}

The issue of education in contemporary society acquires new connotations, determined especially by the unprecedented changes in all areas of social life. The education goes beyond national standards and values and aspires to universality, to the common values of humanity's heritage. Thus lifelong learning occupies an important role in the formation of the personality. Contemporary educational ideal aims at developing the human potential to create a harmonious and creative personality, able to practise the competency with optimal yield. It aims at developing the most important human qualities: attitudes, skills, motivations, ideals etc. As the society is changing, generating new demands in education, it means that man, at his turn, must be a good receptor of the educational action, particularly referring to the artistic phenomenon that is "educational it self " [4], and has a continuous impact on the whole life. Art, that gives the possibility to the subject to live differently and, at the same time, creates the subject's inner world, participates actively at the creation of the individuality, ensuring his "full life" [10]. In general, the art education is efficient when, the taught personality is regarded as an agent, but not an object.

\section{Discussions}

Subject-centered approach in the educational process means that the student is the subject of this process. Consequently, the educational process is to ensure conditions for the student's active participation in it. I. S. Bruner says that to train somebody does not mean storing of information, but it means student's active participation in gathering knowledge [4]. Art, from this point of view, has a well known educational force. According to the European education current perspective, art education is a continuous individual spiritual selfrealization process of the personality. This process is realized through many forms of contact with the fine arts, these being ways of reflecting the universe.

\footnotetext{
${ }^{110}$ Lecturer PhD, „Alecu Russo” State University from Bălţi, Republic of Moldavia, email: cosumov@mail.ru
} 
The Romanian psychologist M. Ştefan asserts: „All education derives from the experience of child social situation" [4], educational environment representing all the conditions under which the educational action develops. In the theory of psychological functions development, the great Russian teacher L. Vîgotskii notices: ,... any function in the child's culture development manifests its double appearance, initially - in the social sphere, then in the psychological one; first in the society as an interpsychological factor, later - inside the child as an intrapsychological category" [5]. In the field of pedagogy, this configuration of the factors existing in the development of an educational act is educational (educative, pedagogical) environment. The concept was defined by the Romanian researcher D. Todoran as ,a structural and functional complex of forces (,subjective" and „objective") which determines the human spiritual growth and development" [8]. The content of education has a larger sphere than the contents of the educational process, the last one being represented only by the suggested and organized by school values. The education includes values which pupils assimilate by methods and means less systemized than the educational ones, outside the school.

The up-to-date vision on European education treats the notion of artistic (musical) education as an individual continuous process of personality spiritual self-realization by multiple forms of contact with the fine arts these being ways of reflecting the universe in which the person is retrieved as a component, musical culture representing the core of personality culture in general. Art education comprises values that students assimilate permanently through methods and means less systematic than those didactic. The family, the religious, cultural and art institutions, media etc. are considered educational resources and they have a great influence on the personality. Spiritual development by / for art is done under the influence of a group of internal and external factors. Internal factors are:

- self-knowledge, that makes the student become aware of his own artistic knowledge / skills / aattitudes;

- student's ability to criticize himself, observing spiritual failures;

- aspiration towards a lofty artistic culture;

- responsibility towards becoming a personality with a developed spiritual culture;

- proper appreciation of cultural and artistic, moral, religious, etc. values;

- desire for a permanent artistic self-improvement.

External factors that determine the spiritual self-education:

- diversification of spiritual and artistic contexts;

- permanent spiritual contact with artistic values.

These conditions, extending the horizon of educational and artistic achievement, focuses more on the extracurricular musical education than on the obligatory musical education in school. This fact leads to a permanent artistic 
artistic musical self-education (Figure 1):

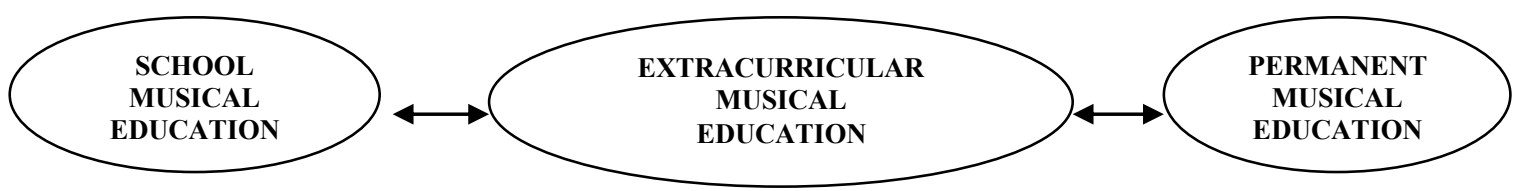

Figure 1. Dimensions musical and artistic education

The idea of lifelong learning is not new. This concept has existed since ancient times, the Greeks and Romans, and later the Arabs mentioned it in the Quran as a religious obligation. "The whole life is a school," says J. A. Comenius (9). N. Iorga states: "That person is intelligent who continually learns himself and teaches the others" [9]. Today, lifelong learning has become a fundamental requirement of the society, determined by: 1. the exponential growth of information and its accelerated outdatedness; 2 . the extraordinary progress of science and technology; 3 . dynamism of social life; 4. the democratization of learning by increasing the aspiration to culture and education, using the leisure time enjoyably.

Learning to learn and developing to develop continually are the requirements of lifelong learning. One learns to be oneself, to be responsive to changes, to be able to anticipate and adapt to them and to become a participant in the social evolution through intellectual and moral autonomy. Lifelong learning is characterized by continuity and universality, integrating all levels and types of education. Thus this type of learning develops a balanced personality with a high degree of autonomy of learning, being able to identify and to use sources of information, to participate in the development of society, to educate other members of the community.

There can be observed the orientation towards lifelong learning, selfeducation in the current reforms on the educational systems of all countries. Curricular and extra-curricular components of lifelong learning are closely connected, aiming at student's development and adaptation to new conditions for the effective use of free time. These two may surely participate at the formation of a creative personality. Schooling, in this context, is an initial stage of lifelong learning and its primary purpose is to teach students how to learn and integrate socio-culturally. The teachers at schools, in this respect, will focus on the widespread use of active-participatory methods, techniques of effective learning, didactic integrated approach. These techniques develop student's capacity for self-assessment and integration in a changing world.

Spirituality means creation, and it involves the communication with an invisible, untouchable universe. This type of communication requires special skills that have to be generated. Inner world - "reconciles, unites, harmonizes, tolerates, cultivates love ..." [6]. Spiritual education is the action and the result of acquiring an elevated level of existence. It is the process of transmission and assimilation of life experience, spiritual / cultural / religious communication with God. It is spiritualization of somatic and psychiatric human beings, spiritualization of body, work, feelings, attitudes and moral faculties. When the 
human being is open for spiritual knowledge, conquest and exploitation of spiritual forces, divine realization, he becomes the essence of the future education. Spiritual development is the perfection of mind, knowledge generation, aesthetic sense education, morality improvement. School, as one of the foundations of human society, has a decisive impact on the formation of personality in all its dimensions.

The artistic education requires a methodological complex approach. It implies formal and extracurricular influences. The formal influences include the impact of certain art disciplines (musical, art, literary education and choreography). The artistic education, as a concept, is developed in the school that has a decisive impact. The extracurricular influences imply all the artistic feelings experienced in informal situations that shape, ultimately, spiritual intelligence pillars of a personality. The formation of the personality's spiritual intelligence goes beyond school, the student in the post-school stage assumes the effort of spiritual self-education carried out in time and space. The means of the personality's reception are much broader and much varied.

Based on the idea of extending education in the context of the selfeducational dimensions development through various means of art initiation of students, the teacher will seek to generate at his pupils an integrated / unified perception of the artistic values. Still, the priority will constitute the formation of intrinsic motivation in the development of the spiritual intelligence, the one's/world's self-awareness through art. Thus, a certain spiritual dependence of art will be developed.

Self-discipline is possible based on education. When the student studies, he thinks about the received information, he has his proper appreciation of the artistic values, thus self-developing and training. At the same time, selfeducation promotes the assimilation of the artistic and educational influences, becoming, consequently, a part of the art education. As a result, the school will have to transmit to the pupils the permanent art self-education, thus leading to an efficient spiritual self-training. School curriculum in music education is an adjusting document, with a purpose to circumscribe the sequence of musicaleducational standards, musical competencies as well as other ways of their integration in everyday situations to which structure the school aspires by all its educational-musical steps.

Thus, music education/by music, as a supremely form of moral, aesthetic, spiritual etc. education extends expressly over school areas creating the context of a continuous music education. In the classification made by UNESCO [6], the education appears in three fundamental aspects: formal music education, nonformal music education and informal music education. Formal music education is a period of intensive musical activity pursuing preponderantly the development of pupils' musical culture. This type of music education includes the totality of musical-educational actions performed consciously and organized in schools of an organized educational system.

The objectives and the content of formal music education are stipulated in school documents scheduled on general-semestral topics, levels and years of 
study, fact that facilitates the conscious guiding of a vast musical culture development in a methodical organized context (curriculum, guidebooks, textbooks, technical aids, specific music education strategies etc.), according to the requirements of the ideal music education in school. Formal music education is a process which limits exclusively to school years and which is more than an introduction to musical culture field and an initial training for a music education that will extend over the entire life.

Non-formal music education designates a reality less formalized, but which also has forming effects. As it results from the content analysis, ways and forms of organization (active forms - general school choir, orchestra of musical instruments for children etc.; passive forms - musical meetings with interpreters and composers, musical excursions etc.), the relation between non-formal music education and formal music education is defined as a complementary one. Nonformal music education supposes the totality of extracurricular musicaleducational actions which develops under organized special conditions. Their mission is to complete and fill formal music education by forms special established in order to enrich the musical culture level, to practice and to improve different availabilities and individual musical competencies.

The main institutions where is achieved this type of music education, are the houses of culture, theatres, clubs, community centres, public libraries etc. By its nature and specific, non-formal music education certifies its properties among which are the great variety of musical forms and contents, differentiation of music activities, forms of organization etc. It is about doing music education under better and more varying conditions, through the same formative influences, but from the perspective of pluri- and interdisciplinarity taking into account the disciplines' interference of the artistic field.

We want to mention that both formal music education as well as the nonformal one are forms of systematic school activities that develop in a planned and organized way being guided by a professional staff in this field. Besides these two forms of school music education, it is required the third one informal music education. This form, compared with the first two - formal and non-formal - is less advantageous. It occurs because of its quality difference. Between music in the classroom and music outside it, between musical environment developed in the context of music education lesson and the extracurricular one, there are almost contradictory.

These factors are a reason for which informal music education can not be the substance and the fundamental basis of music education, but without ignoring the value of its content as well as the extension over the limits of formal education, certified by its existence all lifelong. Thus, informal music education expresses the spontaneous and continuous character of education, which means completely free of any formalization. It represents individual independent musical experiences, experiences acquired in a casual way. Informal education signifies the vital environment and the social ambience in which the individual is. In this hypostasis he acquires information, internalizes 
models of moral behaviour, adopts attitudes, responds to different requests and enriches his spiritual horizon.

Pupil's music culture will be defined only by a close correlation of school music environment and the extracurricular one, its level being directly proportional to the quality of integrity and achievement in a continuous spirit of these two parts. Pursuing the specific of these two types of activities, we conclude:

- both school and extracurricular activities are aimed at the harmonious development of the personality;

- school activities give priority to those extracurricular because the personality initiation in social environment is voluntary and its tendency to self-realization is expressed more efficiently.

Thus, the aim of music education requires moment and perspective musical training of subjects, report of music education to the context in which they develop, being its basic condition. Musical activity and musical environment are two inseparable parts. Musical environment/context facilitates the development of music culture and vice versa, music culture as a component part of spiritual culture will exceed school limits and will confirm the necessity of foundation of musical-cultural context. Extracurricular music context highlights the existence of three dimensions of pupils' independent music activities:

- decontextualization and adjustment of music experience to extracurricular conditions;

- augmentation of the independent musical activities complexity in order to implement diverse music competencies;

- estimation of their own performances and/or difficulties in independent music cognition.

The basic form of school instructive-educative work is music education lesson. But time for this activity is limited representing a ratio of 1 to 23 of the 24 hours of the day. Besides it, the interval that separates music education lessons does not always allow to maintain the continuity between them. If we make a comparative analysis, the extension of music studied during music education lesson and music coexisting outside it, we will notice that the second one is wider and more diverse, both being in agreement, in disagreement and even sometimes in contradiction.

In the field of music education the main problem is - the effects and the consequences of musical environment where pupils live in, problem that can be solved only if the lesson left in child's soul unforgettable impressions, traces that can not be easily erased. Music education lesson is central focus of creating those stimulants. However, outside the school walls, pupils plunge into a controversial music dimension which they are obliged to know independently, without adviser consuming mostly low quality music, a music that influence in an inadequate way the consciousness and the musical liking.

Music education is focused on developing creative personality of pupils. From the pedagogical point of view, it does not mean to force the child to be a „little genius", but to develop his creative personality in the context of his 
integration in social life. Pupil's initiation in the meanings of universal music requires effort. Being directed from educational aspect, the effort is transfigured into enjoyment, pleasure, positive experience which argues for a way of pupils' self-education in terms of his lively, active and original participation to his own development/training. Unlike the lesson, where the connection with music is "guided", aesthetic education situations by the independent, individual action (individual study, doing homework etc.) penetrates deeply each pupil's interior not only at an accompanying life level, but also as an indispensable component of life.

Listening to the music that surrounds him daily, the child will ,search" to discover, individually, those things that were discussed during the lesson. Therefore, during the lesson, children will distinguish the close organic correlation of studied music with life. It implies work, daily exercise, an evolution equivalent to that which forms musicians. By music existing outside the music education lesson, at any age, in any circumstances pupils will feel emotions, many new meanings of life values as well as the values of their own. Music education lesson must open to susceptible musical contents in order to be assimilated by pupils, inclusively outside it, forming competencies at pupils and establishing clear criteria of pursuance, selection and experience of extracurricular music values (Figure 2):

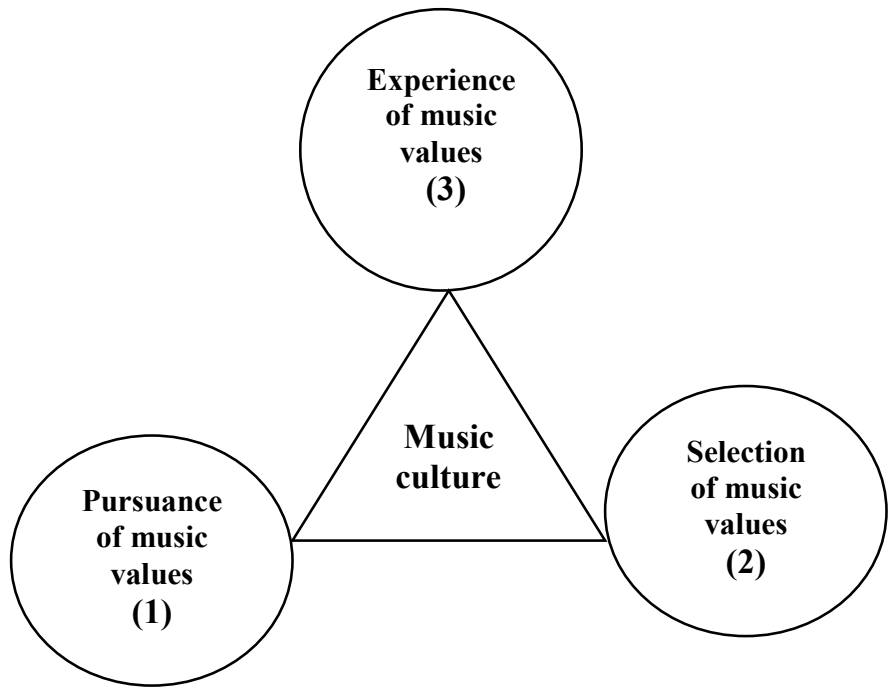

Figure 2. Stages of music culture manifestation

Independent and individual feeling of music outside music education lesson that completes, fills and develops general music culture, is designed to build up a new pupil's attitude for which the relation with music will not be an occasional one, but will achieve the statute of indispensable pupil's spiritual culture practices. The extension of student's autonomy in the acoustic environment outside the lesson is expressed by the growth of its independence to perceive the music. Teaching students to decode the acoustic message of the universe means to build-up knowledge, competences, acquirements and techniques skills and musical creativity (abilities), associated with inherent reasons - of necessity and existence by music. 
For that purpose, Filimon Turcu mentions that "the necessities cause different human emotional states, and only due to these activities they can be perceived as a necessity" [10]. V. S. Merlin points out that "the necessity - gets the motivator nature unless it induces to action" [10]. We get a list of wellknown names from specialty sources, which defines the orientation, the initiation and the adjustment of the musical activities as a system of reasons that interacts and cooperates, further it is manifested in tendencies, interests, aims etc. (I. Gagim, G. Bălan, A. Motora-Ionescu, V. Vasile etc). Thus, Emil Stan reflects in his works, the subjective and personal perception of the objective surrounding reality, generating a certain meaning to the personal image. It results that: "The meaning, the attitude, the position come to light not directly from the content/appearance, but from the relation between the action motivation and its direct result....The motivations, the necessities, the awareness purpose, ....the humanity specific qualities are formed during the entire life" [11].

The motivation problem in the pedagogical musical sphere was treated for the first time by the educationalist D. B. Peric, by the end of ' 60 [2]. He valorizes the indispensability of psychological necessities in order to accomplish different musical activities, as well as the importance of the musical phenomenon as a first-line factor in creation / development of an upward spiritual culture. At its turn - the necessity which appears as a reason of a standing contact with the music requires different forms and means of psychological satisfaction through music. It can be musical listening, concerts, meetings with favorite singers, participation in organization of different musical events etc.

Pupil's extracurricular music activity is the assimilating activity of the musical cultural values, which are considered by the school the efficient ones in human high esthetic culture forming. The purpose of these efforts focuses on the insurance of the functional stability of these two periods. Pupil's musical experience, regarding motivation structures as personality units, subordinates the selection and integration process of the existing musical values. The equilibration and adaptation process of pupil to the musical and cultural external influences will gradually become a function/necessity of these motivation states. The principles that substantiate the process of educational leading through the perspective of musical-artistically reasons to pupils are the following:

a. the awareness of the musical environment, where the pupil lives/will live;

b. the development of the basic musical activities in school;

c. the achievement of the musical culture values and standards in the school period.

\section{Conclussions}

The consequences of applying these principles (in analyzing the student perception of the musical environment) are decisive as methodological value. The extracurricular music motivation activity turns the pupil from a simple receiver/customer of external music influences into an active and selected subject, with an own interior determinism in choosing and releasing adequate 
music attitudes. Having an own motivation structure, the pupil will establish a double relation towards the musical environment: one of independence, which consists of his capacity of react/perceive only the high quality music, the educative one and the other, of dependence, which consists in satisfying psycho-spiritual state of necessity for musical phenomenon. In this context, the teacher of music Education is the main factor who will pursue the progressive dynamics in forming/ developing pupil's music culture and will guide in this direction, the music education development in extracurricular conditions as well as pupil's training for a continuous music education.

\section{References}

1. Chiş, V. (1992). Strategii de predare şi învăţare. Bucureşti: Ştiinţifică

2. Cosmovici, A. (1994). Învăţarea şcolară. In Cosmovici, A. (Ed.) Psihopedagogie, Iaşi: Ştiinţifică

3. Curriculum şcolar (2010). Chişinău: Prut Internaţional

4. Dave, R. (1991). Fundamentele educaţiei permanente. Bucureşti: Humanitas

5. Gagim, I. (2003). Dimensiunea psihologică a muzicii. Iaşi: Timpul

6. Guţu, V. (2005). Managementul schimbării în cadrul educaţional. Chişinău: C.E.P.

7. Joiţa, E. (1999). Pedagogia: ştiinţa integrativă a educaţiei. Iaşi: Polirom

8. Nicolescu, M. (1995). Modelul uman şi idealul educativ: Antologie de texte. Bucureşti: Editura Didactică şi Pedagogică

9. Okon, W. (1978). Invăţământul problematizat în şcoala contemporană. Bucureşti: Editura Didactică şi Pedagogică

10. Roco, M. (2001). Creativitate şi inteligenţă emoţională. Bucureşti: Ştiinţifică

11. Stan, E. (2004). Pedagogie postmodernă. Iaşi: Timpul

12. Vasile, V. (2004). Metodica educaţiei muzicale. Bucureşti: Muzicală 